\title{
A Bleeding and Broken System Mark Zammit
}

$\mathrm{I}_{n=1}^{n+m}$

am a proud and active advocate of prison reform, racial justice and LGBTQ

rights, as well as a harm reduction activist. I also have the unfortunate knowledge and wisdom of twenty-one years in the federal system and a decade or so in the provincial system. I am currently incarcerated at the Ontario Correctional Institute. Before arriving here, I had to spend the better part of a year at the ill-fated, ill-ran and infamous Toronto South Detention Centre.

I will do whatever necessary to have my/our voices heard and protect our basic human rights. As a young adult, I always had the desire to help others to the point that it was considered a fault or weakness. I did not dream of becoming a doctor or a surgeon or anything of the sort. I wanted to fight poverty and the so-called justice system that has taken away so many dreams.

The racial, gender, and sexual orientation prejudices and bigotry that runs rampant throughout the Canadian injustice system are serious forms of legal discrimination in our society. We must remove all bias from our "justice system" and make sure that the administration of law is done reasonably and fairly. The lack of court resources and the lengthy amount of time it takes for the accused to get a trial or a preliminary hearing is also a massive problem. The eighteen to thirty months many of us wait for our day in court is a lot of time during which our loved ones lose faith, strength, money and, in turn, also suffer while we await trial. Men and women lose their homes, families and jobs, while children suffer parentless existences. Landlords and others steal our property to make up for due rent and/or loans.

The accused who are put through the "justice system" are told that they are innocent until proven guilty. They are also told they have the right to an allegedly fair and unbiased hearing. Nevertheless, the extensive damage done to the accused men and women awaiting a preliminary hearing, trial, sentencing, bail or even acquittal leaves scars on one's soul and sense of self.

Although the Canadian Charter states that "we all have the right not to be subject to cruel and/or unusual punishment", there are prisoners who are locked down 24 hours a day due to short staffing issues. They are lucky if they get one phone call and a shower every three to five days. They get next to zero fresh air. Their access to clean laundry is extremely limited, if any. They have their books, magazines and art supplies confiscated. They are provided with meals that would not fill a school child's belly and, at times, receive rotten fruit or mouldy bread. They are denied hot water for their 
ministry-approved and allotted coffee and tea. They receive the worst health care Canada has to offer. They suffer beatings, belittlement and ridicule at the hands of prison staff. If these conditions and treatments are not deemed cruel and unusual punishment by Canadian standards, what is?

If the goal of the prosecutor is to find the truth, why is it that the Crown looks "only" for a conviction even if the evidence proves otherwise? They chase a conviction, not the truth, by any means necessary. This biased behaviour throughout our "justice system" makes the administration of law and punishment neither fair nor reasonable. Canadians must come up with new strategies and fixes. Denied bail and the pursuit of trials are nothing more than perfect examples of how our court system looks only at our record, ignoring our humanity to quickly assign us a number/position. Not once has the "justice system" paused to consider what led me down this path. We are not born bad or evil.

The human mind is inclined to think in a particular way. When the mind is led by negative beliefs and stereotypes through media representations, people start to loath people of colour, the LGBTQ community and people living with addiction. These negative biases are disgusting and deplorable on many levels. The media paints the picture that will sell in order to create profit and maintain notoriety, which are stereotypes that seep into our judicial system. This is unprofessional and disgraceful.

In closing, what needs to be done is not a quick or easy fix. The system is not broken - it is shattered and it needs to be replaced.

\section{ABOUT THE AUTHOR}

Mark Zammit is from Regent Park in Toronto. He is 49 years old and an advocate for prison reform, harm reduction, and the rights of racialized and LGBTQ people. 